Кушнір А. О., аспірант кафедри української літератури і компаративістики Київського університету імені Бориса Грінченка

\title{
ІЄРАРХІЯ ЦІННОСТЕЙ У РОМАНІ ЕСПІДО ФРЕЙРЕ «ЗАМОРОЖЕНІ ПЕРСИКИ» ЯК ВІДБИТОК НАЦІОНАЛЬНОЇ МЕНТАЛЬНОСТІ
}

У статті розглядається певна ієрархічність панівних концептів у романі Еспідо Фрейре «Заморожені персики» як відображення ціннісних орієнтирів іспанського суспільства сучасності. Аналіз зосереджується на власне «жіночому» сприйняттю оточуючої реальності, адже проблема місия жінки в іспанському суспільстві завжди була наскрізною в творах іспанських письменників і особливо письменниць. Зміни на всіх рівнях суспільного життя, включно із законодавчими нововведеннями, значно вплинули як на сприйняття жінки іншими, так і на ї̈ сприйняття самої себе, щяо безсумнівно знайшло вираження і в літературній творчості.

Ключові слова: жіночі цүінності, ієрархія цінностей, базові конщепти, іспанська жіноча проза, концептуальна картина світу. 
В статье рассматривается определенная иерархичность господствуюших концептов в романе Еспидо Фрейре «Замороженные персики» как отражение иенностных ориентиров испанского общества современности. Анализ сосредотачивается на собственно «женском» восприятии окружающей действительности, ведь проблема места женщины в испанском обществе всегда была сквозной в произведениях испанских писателей и особенно писательнии. Изменения на всех уровнях общественной жизни, включая законодательные нововведениями, значительно повлияли как на восприятие женщинь другими, так и на ее восприятие самой себя, что, несомненно, нашло выражение и в литературном творчестве.

Ключевые слова: женские ценности, иерархия ценностей, базовые концепты, испанская женская проза, конщептуальная картина мира.

The article deals with a certain hierarchy of the ruling concepts in the novel "Frozen peaches» by Espido Freire as a reflection of values of Spanish society of today. The analysis focuses on a peculiar "women's» perception of reality, as the problem of the women's place in Spanish society has always been prevailing in the works of Spanish writers, especially female writers. Changes at all levels of public life, including legislative innovations significantly influenced both a woman's perception by other women, and her perception of herself that undoubtedly found expression in literary works.

Key words: feminine values, the hierarchy of values, basic concepts, the Spanish women's prose, conceptual picture of the world.

Метою статті є спроба виявити та дослідити основні текстові концепти, що стосуються вираження ціннісних пріоритетів в жіночій прозі на базі роману Еспідо Фрейре «Заморожені персики», а також прослідкувати відображення через них власне іспанської ментальності.

Об’єктом статті є роман Еспідо Фрейре «Заморожені персики» як відбиток іспанської ментальності.

Предметом статті є стрижневі концепти у романі «Заморожені персики» та їх ієрархічна побудова.

Говорячи про ієрархію цінностей в літературі, слід в першу чергу виділити основні традиційні концепти пов'язані 3 ціннісними орієнтирами жінок у тому чи іншому суспільстві. У нашому випадку саме суспільства Іспанії.

Варто зазначити, що в іспанській культурі традиційні жіночі цінності (як і загалом асоціативні ряди, що виникають при сприйнятті поняття «жінка»), у більшості співпадають із «загальнолюдськими» уявленнями. Однак, не можна ігнорувати той факт, що вони надзвичайно розширились, порівняно 3 попередніми історичними етапами в розвитку суспільства Іспанії. Такі традиційні цінності як кохання, одруження (чоловік), сім’я, дім та материнство 
продовжують бути актуальними для жінок. У той же час, відображення чого ми знаходимо і в літературі, їхня першочерговість нерідко піддається сумніву. На передній план виходять концепти дружби, самореалізації, дорослішання та навіть самоідентифікації.

У своєму романі «Заморожені персики» Еспідо Фрейре часто проводить паралелі між світосприйняттям старшого та молодшого поколінь. Значну увагу вона постійно приділяє ставленню до вищезазначених цінностей. Відношення до кохання та одруження нею зображуються як дещо спірні. 3 одного боку, іронізується з приводу необхідності вийти заміж (чим раніше, тим краще) та завести сім’ю. Для молодого покоління традиційні пріоритети здаються перебільшеними у своїй вагомості. У тексті зустрічаємо такі репліки з вуст старшої жінки:

«-Яка Ельза? Мігелева чи Карлосова?

Няня потягнула за клубочок сімейних відносин. Ельза велика, дочка Мігеля. Художниця, щуо так ніколи і не вийила заміж» [Freire 1999:57].

Характеристики процесу згадування дійсно постають в іронічному світлі. На відміну від попередніх «занурень» в оніричний стан героїв, який авторка описувала ледь не з благоговійним захватом, тут бачимо ніби вибірку з хроніки. Немає того плавного, майже невідчутного переходу від реальності до світу спогадів. Натомість зустрічаємо коротку метафору «потягнула за клубочок ciмейних відносин», в якій в той же час дається прихована негативна оцінна характеристика складних сімейних зв’язків, а потім, 3 відтінком сухої прагматичності, перелічуються специфічні риси згадуваної особи та iii modus vivendi, де важливе місце відводиться сімейному стану, а саме тому, що особа ще не одружена. Більш того, помітна граматична пов'язаність між фактами «неодруженості» та «роботи художниці». Мається на увазі причинно наслідковий зв'язок між цими двома частинами речення. Таким чином, негативною конотацією маркується також професійна реалізованость героїні. Художник - професія не надійна, що не приносить грошей, а героїня ще й не 
одружена. Письменниця акцентує увагу читача на цій стороні упередженості суспільства щодо положення жінки в ньому 3 певною гіркою саркастичністю.

Пізніше в тексті зустрічаємо короткий діалог між двома молодими жінками, в якому, однак, яскраво передається їх позиція із зазначеної проблеми: « - Зрештою - сказала Бланка, піднявши брову -. Зрештою виходить так, щуо мати хлопияя корисно.

- Сподіваюся, щуо ні - відповіла Ельза - : Це б зруйнувало всю твою життеву філософію» [Freire 1999:94].

На відміну від попередньої цитати бачимо позитивне ставлення оповідачки до описуваного, що виражається в легкій іронії. Цей ефект досягається використанням гіперболізованих тверджень. Отже помічаємо ще одне підтвердження переходу концепту відносин / одруження у свідомості молодого покоління від центральної позиції до маргінальності.

В той же час авторка не нівелює важливість кохання в житті жінки, хоча i надає йому відтінок неможливості в умовах зміни ролей жінки та чоловіка в суспільстві. Це також пов'язано зі специфічним зображенням чоловічих персонажів письменницею. Молоде покоління чоловіків змальовується таким чином, що побудова стосунків 3 ними виявляється якщо не марною справою, то надзвичайно важкою:

" - Родріго - згадала вона, $i$ спека перестала бути приємною $i$ перетворилась на задушливу. Вона знову була зла на нього, на його бездушність та манеру поведінки. Вони не розмовляли. Минулого вечора жоден не подзвонив іншому. Він не переживав за неї, не запропонував їй жодного вирішення проблеми. Вони витрачали час замість того, щуоб займатися чимось дійсно важливим. Такими $і$ є чоловіки: егоїсти, корисливі та керовані хіттю» [Freire 1999:128].

У процитованому фрагменті стикаємося 3 використанням значної кількості епітетів, що безпосередньо формують картину емоційного стану героїні, іï розчарування та гнів через опис характеристик іншого персонажа. Однак нижче зустрічаємо: 
«Вона також була налякана. Вона не ие хотіла сказати. Прийди, Родріго, кохай мене, не полишай мене, не дозволяй мені думати, втішай мене, скажи мені те, що я хочу почути, ти маєш це знати, ти знаєш мене, ти кохаєш мене. Але натомість кажу:

- Сама не тямлю, що кажу. Я тобі передзвоню пізніше, Родріго.

Він поклав слухавку не відповівши, так $i$ не дізнавщись чи вона почула його вибачення» [Freire 1999:129].

Попри все авторка ніби стверджує, що прагнення бути коханою притаманне кожній жінці. Наказова форма вираження в даному випадку знову ж таки виконує функцію підсилення ефекту значущості сказаного. Йдеться не про опис емоційного а стану, а про його безпосередній прояв у репліках.

Звертаючись до проблеми самоідентифікації, як ще одного важливого концепту в ієрархічній побудові цінностей, варто зазначити, що вона $\epsilon$ актуальною саме в зв'язку з темою дорослішання. Даний концепт окреслений письменницею у романі «Заморожені персики» надзвичайно чітко, переплітаючись 3 основною сюжетною лінією. «Самоідентифікація», за трактовкою Фрейре, це неповторність особистості, іiі відмінність від інших, розуміння власного місця в світі та в соціумі.

«Вона звичайно нічого не знала про дівчинку Ельзу. Знала лише, щзо дідусь з бабусею мали дочку з таким іменем. Вона ж, $i$ ï двоюрідна сестра завдячували ій іменем.

Ельза велика знала, щңо иее була така собі тітонька з двома племінницямитезками, вона могла б поневірятися по світу, потрапляючи в халепу при будьякому вдалому випадку. Здавалося правдоподібним, щзо одного дня ії знайдуть завдяки якійсь бюрократичній помилці.

Ельзу велику це непокоӥло, коли вона була ще підлітком; вона ненавиділа своє ім'я і трималася думки, що забагато однакових імен призводили лише до хаосу і плутанини» [Freire 1999:27].

Неодноразово зустрічаємо стилістичний прийом іронії в поєднанні 3 іншими риторичними фігурами, такими як гіпербола та метафора. Останні в 
даному випадку слугують підсилювачами ефекту іронії, роблять його яскравішим, образнішим. Іронія ж, окрім гумористичної, виконує також i емоційно-оцінну функцію. Головна героїня роздратована та невдоволена станом речей в своєму житті. Вона фактично була позбавлена вибору «ким» бути у власній сім’ї. Названа в честь іншої людини, особливо в підлітковому віці, вона відчуває себе залежною від долі тієї, іншої дівчини (крім того, ще одного члена сім’ї назвали тим самим ім’ям). Таким чином, в уявленні жінки переплітаються концепти дому, сім’і, дорослішання та самоідентифікації.

Ще одна цінність, що займає надважливе положення в канві роману Фрейре $\epsilon$ дружба. Дослідження тлумачень «дружби» дають підстави стверджувати, що це - особливі стосунки, засновані на спільності інтересів, взаємній прихильності, духовній близькості; це - «індивідуально-виборні відносини, щуо можуть характеризуватися процесами зближення, взаємними очікуваннями відповідних почуттів та переваг» [Вежбицкая 1996:330]. Необхідно зауважити, що «дружба» - це єдине з усіх емоційних почуттів, яке потребує взаємності. Загальновідомо, що кохати, ненавидіти, навіть бути байдужим можливо в одностайному порядку, але дружити без взаємності неможливо. В романі «Заморожені персики» дійсно бачимо, що концепт дружби в понятті головної героїні є ширшим за концепт кохання (у вузькому семантичному понятті романтичних відносин 3 особою протилежної статі). Частіше зустрічаємо позитивні конотації саме цього типу відносин:

«Він також не міг нічого зрозуміти. Оглянув листа $i$ вивернув конверт навиворіт.

- Це не може бути Бланка? - спитав він, тому щзо вважав ї̈ здатною на будь-яке диваитво.

Щоб виключити таку можливість Ельза взяла телефон та сповістила Бланку. Та нічого не знала. Ельза повернулася до Родріго з виглядом тріумфу на обличчі, щуо абсолютно не відповідав ситуації» [Freire 1999:55].

Остання фраза підкреслює власне розуміння головною героїнею особливостей iї відносин 3 подругою. Вона сама констатує парадоксальність 
власної реакції, однак неприємні припущення іiі «коханого», його невисока оцінка моральних якостей подруги (здатна на будь-яке диващтво) обурює головну героїню. Ї̈̈ реакція являє собою яскравий приклад домінування поняття-цінності «дружби»над «коханням».

У подальшому в тексті зустрічається ще більше підтверджень цього явища. Якщо на опис відносин з подругою відведено значну частину тексту, де відчувається особливий теплий тон манери написання, то відносини 3 нареченим описуються лише як додатковий матеріал або «ненароком» розкриваються через діалоги. «Коли вони вирішили пращуювати разом, изе було так ніби все встало на свої місия. Вони були подругами щуе з коледжу, навчалися за одним і тим же фахом; якби не проблема Бланки, щзо просто непереварювала ділити з кимось житло, вони б жили разом. Бланка зосередилась на фотографії, а Ельза велика на живописі, але іноді вони використовували змішані техніки, щуо Ельзі дуже подобалось, і якщо одна з ним з чимось не справлялася, то інша обов'язково їй допомагала. Це їх розважало. Коли Бланка завершувала якийсь портрет, вони обидві заходилися сміхом» [Freire 1999:73].

3 перших же рядків помічаємо яскраву, характеризуючу метафору. Зустріч 3 подругою порівнюється 3 природним ходом речей, зумовленим непереборними обставинами щасливого випадку. Наголошується на тому, що одна жінка доповнює іншу. При чому чоловік не може претендувати на таке ж взаєморозуміння. Отже інформативна наповненість тексту при окресленні концептів «дружби» та «кохання» відчутно різна.

Крім того основним змістом дружби є спілкування з людиною, засноване на взаємній схожості, знанні якостей цієї людини і любові, яке приносить мир і спокій, воно має початок, може бути перервано і потім відновитися. Друг протиставляється ворогу.

Ми вже зустрічали неодноразове підтвердження тому, що відносини між жінками набувають інтимнішого характеру ніж відносини між чоловіком i жінкою. В даному романі увага концентрується саме на неможливості головної 
героїні знайти порозуміння 3 найближчими їй людьми (родина, наречений), неможливості довіритись, пов’язане 3 ймовірним упередженим ставленням. Перепоною стає вікова або ж гендерна відмінність героїв. Однак ці перепони зникають у спілкуванні 3 подругою. Вони - молоді представниці свого покоління, що розуміють одна одну як в емоційному, так і в професійному планах: «Вона знайшла папір і відкрила вікно перед тим як сісти. I заглибилась y сповнену спеки подорож, у густий та рідний запах дідусевої домівки; ияі деталі порадували б Бланку. 3 нею можна було позбутися маски холодності, можна було заплакати, і ї̈ не непокоїло, щуо, отримавщи листа, та зрозуміє, щзо вона плакала» [Freire 1999:46].

Як бачимо, наявним є контраст 3 попередніми висловлюваннями героїні. Перед батьками та нареченим героїня стримує себе, не дозволяє іншим довідатися про свій страх, слабкість (це часто виражене невербальними засобами: паузами, інтонацією, тоном, що виходить 3 приміток авторки). Перед ними треба бути сильною, впевненою жінкою, щоб не втратити незалежність, яку з такими труднощами вона здобула. Спілкуючись з приятелькою, героїня говорить про справжню відвертість, відділення від звичної маски холодної впевненості. 3 подругою ж вона на рівних і не має чому прикидатися, грати роль нав'язану сім'єю чи суспільством.

Таким чином, письменниця досить чітко розставляє акценти в цінностях жінки. Базові концепти дружби та самоідентифікації (включно 3 професійною) стають пріоритетними. Вони відіграють важливу роль в репрезентації світогляду жінки i найчастіше забарвлені позитивною конотацією. Письменниця досягає даного ефекту найчастіше не через семантику конкретно обраних окремих слів, а через специфіку їх сполучення. Кожна сентенція, репліка чи твердження відображають концептуальну картину світу героїв саме у своїй цілісності, а не в сумі налічуваних у ній різнородних компонентів.

Надзвичайно велика частина твору присвячена зображенню кризи сім’ї та родинних зв’язків, проблемі непорозуміння поколінь. Іронізується ставлення до інституту сім’ї старшого покоління. Найчастіше для критики авторка обирає 
саме стилістичний прийом іронії. Однак, в іï манері письма, іронія не є злою, дуже рідко переходить в сарказм. Фрейре намагається зрозуміти витоки конфліктів між старшими та молодими людьми, шукає можливі варіанти їх вирішення. Тому можемо зробити висновок, що для даної письменниці $\epsilon$ характерним розуміння концепту «сім’я» як однієї з найважливіших складових частин формування особистості як такої. Родина сприймається як вихідна точка, з якої бере свій початок та в подальшому розвивається особистість, а отже й ігнорувати проблеми, які в ній виникають є неприпустимим.

У своїх романах Еспідо Фрейре найбільшу увагу приділяє саме цінності особистісних відносин між людьми. I хоча соціо-політичний аспект змін в країні також наявний в їі творчості, він не є справді яскраво вираженим. Досить часто письменниця переносить своїх героїв в уявні міста, де скоріше характеризує власне іспанський менталітет, саму душу народу, не зосереджуючись на деталях. Через дослідження соціо-політичних змін, вона, наприклад, вказує на непристосованість попередньої моделі ролі жінки в суспільстві до сучасних умов іï (жінки) життя. Однак принципово важливим все таки залишається саме внутрішній світ головної героїні та людей, що ऑiі оточують.

Таким чином бачимо, що вже неодноразово зазначені традиційні жіночі цінності все ще знаходять відображення в сучасній жіночій творчості. Вони постають в іншому світлі, змінюють свою пріоритетність, завдяки історичним та політичним змінам до них додаються і дещо нові (перш за все професійна самореалізіція жінок), однак вони все одно залишаються актуальними, прояви чого ми і змогли дослідити на письмі в романах Еспідо Фрейре.

\section{БІБЛІОГРАФІЯ}

Бліхар В. С. Ієрархія цінностей як життєво значима засада формування особистості [Електронний ресурс] / В’ячеслав Степанович Бліхар. - 2010. Режим доступу до ресурсу: http://www.stattionline.org.ua/vornka/38/3396iyerarxiya-cinnostej-yak-zhittyevo-znachima-zasada-formuvannya-osobistosti.html. 
Вежбицкая А. Язык. Культура. Познание / Вежбицкая А. : [пер. с англ. : отв. ред. и сост. М. А. Кронгауз]. - М. : Рус. словари, 1996. - 416 с.

Шишкова Т. Н., Попок Х.-К. Л. Стилистика испанского язика. - Минск: Вышэйшая шк., 1989. - 135 с.

Freire Espido. Melocotones helados.- Barcelona : Planeta Editorial, 1999. 136 р. переклад цитат власний (Кушнір А. О.) 